\title{
PENGARUH MODEL PEMBELAJARAN KOOPERATIF TIPE GROUP INVESTIGATION (GI) TERHADAP PENGETAHUAN KONSEPTUAL SISWA PADA MATERI POKOK KINEMATIKA GERAK LURUS KELAS X SEMESTER I SMA N 3 MEDAN T.P 2015/2016
}

\author{
Fahruroji dan Ridwan Sani \\ Jurusan Fisika FMIPA Universitas Negeri Medan \\ Jalan Willem Iskandar Pasar V Medan, Sumatera Utara \\ Fahru.unimed@gmail.com
}

\begin{abstract}
ABSTRAK
Penelitian ini bertujuan untuk mengetahui pengaruh model pembelajaran kooperatif tipe Group Investigation (GI) terhadap pengetahuan konseptual siswa pada materi pokok kinematika gerak lurus. Populasi penelitian ini adalah seluruh siswa kelas X SMA N 3 Medan yang berjumlah 11 kelas. Pengambilan sampel dilakukan dengan cara cluster random sampling dengan jumlah sampel sebanyak 42 orang untuk kelas eksperimen dan 43 orang untuk kelas kontrol.Jenis penelitian ini adalah quasi experiment. Sebelum pembelajaran diberikan pada kedua kelas terlebih dahulu dilakukan pretes. Untuk kelas eksperimen diperoleh nilai rata-rata 44,7619 dan untuk kelas kontrol diperoleh nilai rata-rata 45,9302. Berdasarkan hasil uji normalitas dan homogenitas pretes siswa diperoleh bahwa data kedua kelas sampel adalah berdistribusi normal dan homogen dengan uji t diperoleh bahwa kemampuan awal kedua kelas sama. Selanjutnya, diberi perlakuan dengan model pembelajaran kooperatif tipe GI pada kelas eksperimen dan pembelajaran konvensional pada kelas kontrol. Setelah pembelajaran diberikan kemudian pada kedua kelas sampel dilakukan postes. Diperoleh nilai rata-rata 75,8333 untuk kelas eksperimen dan nilai rata-rata 64,5349 untuk kelas kontrol. Dari hasil uji normalitas dan homogenitas postes siswa diperoleh bahwa data kedua kelas sampel adalah berdistribusi normal dan homogen. Dari hasil uji hipotesis $t_{\text {hitung }}=4,1096$ dengan taraf nyata $\alpha=0,05$ diperoleh $t_{\text {tabel }}=1,6662\left(t_{\text {hitung }}>t_{\text {tabel }}\right)$ yang berarti Ha diterima, sehingga disimpulkan bahwa ada perbedaan hasil belajar siswa akibat pengaruh model pembelajaran kooperatif tipe group investigation (GI) pada materi pokok kinematika gerak lurus di kelas X semester I SMA N 3 Medan T.P. 2015/2016.
\end{abstract}

Kata kunci: kooperatif tipe GI, pengetahuan konseptual, kinematika gerak lurus.

\section{PENDAHULUAN}

Pendidikan merupakan proses mendidik, yaitu suatu proses dalam rangka mempengaruhi siswa agar mampu menyesuaikan diri sebaik mungkin dengan lingkungannya, sehingga akan menimbulkan perubahan dalam dirinya. Sistem pendidikan yang baik juga berperan penting dalam meningkatkan efisiensi pendidikan. Berbagai upaya telah dilakukan pemerintah dalam meningkatkan kualitas pendidikan, diantaranya pengembangan atau penyempurnaan kurikulum, melengkapi sarana dan prasarana pendidikan, meningkatkan kualitas guru melalui sertifikasi, pengembangan sistem penilaian hasil belajar dan sebagainya.

Salah satu karakteristik fisika adalah mempunyai objek yang bersifat real (nyata). Sifat real ini merupakan salah satu faktor 
pendukung yang dapat membantu siswa mempelajari fisika. Akan tetapi kenyataannya, seperti yang peneliti alami saat menjalani Program Pengalaman Lapangan Terpadu (PPLT) di SMKN 1 Lubuk Pakam menunjukkan bahwa fisika termasuk mata pelajaran tersulit di Sekolah. Sehingga, kebanyakan siswa tidak menyukainya. Apalagi melihat kurangnya pendidik dalam menerapkan konsep fisika. Karena pembelajaran fisika yang diajarkan oleh guru di sekolah ini masih bersifat teacher-centered, yang berarti guru hanya menyampaikan fisika tersebut sebagai pelajaran yang menghapal rumus saja. Akibatnya siswa merasa bosan dan tidak tertarik untuk mempelajarinya. Berdasarkan hasil observasi yang dilaksanakan pada tanggal 5 dan 7 Januari 2015 di Sekolah SMAN 3 Medan. Berdasarkan hasil wawancara peneliti kepada salah satu guru bidang studi fisika yang mengajar di SMAN 3 Medan mengatakan bahwa:

"Siswa cepat bosan dalam belajar fisika. Sehingga menyebabkan nilainilai siswa masih banyak yang di bawah KKM yaitu dengan nilai KKM 70".

Berdasarkan observasi, metode pembelajaran yang beliau lakukan merupakan metode yang sederhana. Sehingga siswa kurang tertarik untuk belajar fisika. Oleh karena itu, perlu adanya suatu inovasi dalam pembelajaran fisika yakni perubahan dalam model pembelajaran. Adapun model pembelajaran yang dapat menyiapkan siswa untuk mampu berpikir logis, kritis, kreatif serta dapat berargumentasi di depan kelas dengan baik adalah dengan menggunakan Model Pembelajaran Kooperatif Tipe Group Investigation (GI).

\section{METODE PENELITIAN}

Penelitian ini dilaksanakan di SMAN 3 Medan yang pelaksanaannya pada semester I T.P. 2015/2016. Penelitian ini dimulai pada bulan Juli 2015 sampai bulan agustus 2015 .
Populasi dalam penelitian ini adalah seluruh seluruh siswa kelas $\mathrm{X}$ semester I SMAN 3 Medan yang berjumlah 11 kelas yang berjumlah 520 siswa. Pengambilan sampel dilakukan secara acak (cluster random sampling) dimana setiap kelas memiliki kesempatan yang sama untuk menjadi sampel penelitian. Sampel yang diambil sebanyak dua kelas yang terdiri dari satu kelas kontrol yakni kelas X - 5 dan satu kelas eksperimen yakni kelas X - 11 .

Penelitian ini termasuk jenis penelitian quasi eksperimen. Untuk mengetahui hasil belajar fisika siswa dilakukan dengan memberikan tes. Desain penelitian yang digunakan adalah Two Group Pretes - Posttes Design. Rancangan penelitian ini ditunjukkan pada Tabel 1 .

Tabel 1. Two Group Pretes - Posttes Design

\begin{tabular}{|l|c|c|c|}
\hline \multicolumn{1}{|c|}{ Kelompok } & Pretes & Perlakuan & Postes \\
\hline $\begin{array}{l}\text { Kelas } \\
\text { Eksperimen }\end{array}$ & $\mathrm{T}$ & $\mathrm{X}$ & $\mathrm{T}$ \\
\hline $\begin{array}{l}\text { Kelas } \\
\text { Kontrol }\end{array}$ & $\mathrm{T}$ & $\mathrm{X}$ & $\mathrm{T}$ \\
\hline
\end{tabular}

Sumber: Arikunto, (2010)

Keterangan :

$\mathrm{T}_{1}$ :Pretes diberikan kepada kelas eksperimen dan kelas kontrol sebelum diberi perlakuan

$\mathrm{T}_{2}$ :Postes diberikan setelah perlakuan pada kelas eksperimen dan kelas kontrol

$\mathrm{X}$ :Pengajaran dengan menerapkan model pembelajaran kooperatif tipe GI

Y :Pengajaran dengan menerapkan pembelajaran konvensional

Hasil pretes yang diperoleh dilakukan uji normalitas, uji homogenitas dan uji $\mathrm{t}$ untuk menentukan apakah data berdistribusi normal, homogen dan kedua kelas memiliki kemampuan awal yang sama (Sudjana, 2005). Selanjutnya kedua kelas diberi perlakuan yang berbeda, kelas eksperimen menggunakan model kooperatif tipe GI dan kelas kontrol menggunakan pembelajaran konvensional. Setelah itu diberi postes, hasil yang diperoleh dilakukan kembali uji normalitas, uji homogenitas dan uji t untuk 
menentukan apakah hasil belajar siswa berdistribusi normal, homogen dan ada perbedaan yang signifikan antara hasil belajar kedua kelas yang menunjukkan bahwa ada pengaruh atau tidak model kooperatif tipe GI.

\section{HASIL DAN PEMBAHASAN Hasil Penelitian}

Awal penelitian kedua kelas diberikan

\begin{tabular}{|c|c|c|c|c|c|}
\hline $\begin{array}{c}\text { Eksper } \\
\text { imen }\end{array}$ & 0,1003 & $\begin{array}{c}0,136 \\
3\end{array}$ & 0,1305 & $\begin{array}{c}0,136 \\
3\end{array}$ & $\begin{array}{c}\text { Nor } \\
\mathrm{mal}\end{array}$ \\
\hline $\begin{array}{c}\text { Kontro } \\
1\end{array}$ & 0,1315 & $\begin{array}{c}0,136 \\
3\end{array}$ & 0,0811 & $\begin{array}{c}0,136 \\
3\end{array}$ & $\begin{array}{c}\text { Nor } \\
\mathrm{mal}\end{array}$ \\
\hline
\end{tabular}

Pengujian

homogenitas dilakukan untuk mengetahui apakah kelas sampel berasal dari populasi yang homogen. Hasil uji homogenitas data yang diperoleh dapat dilihat pada Tabel 3.

Tabel 3. Hasil Uji Homogenitas Data tes uji kemampuan awal (pretes) yang bertujuan untuk mengetahui apakah kemampuan awal siswa pada kedua kelasPretes sama atau tidak. Berdasarkan data hasilkelas penelitian diperoleh nilai rata-rata pretes eskperime $^{-1}$ siswa pada kelas eksperimen sebelum diber ${ }^{\mathrm{n}}$ Pretes perlakuan dengan model pembelajaran kelas kooperatif tipe GI sebesar 45 sedangkan dikontrol kelas kontrol diperoleh nilai rata-rata pretesPostes siswa sebesar 46. Selanjutnya kelaskelas eksperimen dan kelas kontrol diberikan ${ }^{\text {eksperime }}$ perlakuan yang berbeda. Kelas eksperimen menggunakan model kooperatif tipe GI dan kelas kelas kontrol menggunakan pembelajarankontrol konvensional. Setelah kedua kelas diberi perlakuan, masing-masing kelas diberi postes untuk melihat adanya perbedaan akibat diberikan perlakuan pembelajaran yang berbeda. Dari data postes kedua kelas diperoleh nilai rata-rata postes untuk kelas eksperimen sebesar 76 dan nilai rata-rata postes kelas kontrol sebesar 65 yang ditunjukkan pada Gambar 1.

\section{Gambar 1. Data Pretes Dan Postes Kelas} Eksperimen dan Kontrol

Sebelum dilakukan uji hipotesis terlebih dahulu dilakukan uji prasyarat data yaitu uji normalitas menggunakan uji Lilliefors. Hasil uji normalitas yang diperoleh dapat dilihat pada tabel 2 .

Tabel 2. Hasil Uji Normalitas Data Pretes dan Postes Kelas Eksperimen dan Kelas Kontrol

\begin{tabular}{|c|c|c|c|c|c|}
\hline \multirow{2}{*}{$\begin{array}{c}\text { Kelom } \\
\text { pok }\end{array}$} & \multicolumn{2}{|c|}{ Data Pretes } & \multicolumn{2}{c|}{ Data Postes } & Kes \\
\cline { 2 - 4 } & $\mathrm{L}_{\text {hitung }}$ & $\mathrm{L}_{\text {tabel }}$ & $\mathrm{L}_{\text {hitung }}$ & $\mathrm{L}_{\text {tabel }}$ & $\begin{array}{c}\text { imp } \\
\text { ulan }\end{array}$ \\
\hline
\end{tabular}

\begin{tabular}{|c|c|c|c|c|c|}
\hline Data & $\begin{array}{c}\mathrm{Kel} \\
\text { as }\end{array}$ & $\begin{array}{l}\text { Rata } \\
\text {-rata }\end{array}$ & $\mathrm{t}_{\text {hitung }}$ & $\mathrm{t}_{\text {tabel }}$ & $\begin{array}{c}\text { Keter } \\
\text { anga } \\
\mathrm{n}\end{array}$ \\
\hline \multirow{4}{*}{ Pretes } & Eks & 44,7 & \multirow{4}{*}{$\begin{array}{c}- \\
0,416 \\
1\end{array}$} & \multirow{4}{*}{$\begin{array}{c}1,999 \\
2\end{array}$} & \multirow{4}{*}{$\begin{array}{l}\text { Kem } \\
\text { ampu } \\
\text { an } \\
\text { awal } \\
\text { sama }\end{array}$} \\
\hline & peri & 619 & & & \\
\hline & Kon & $\overline{150}$ & & & \\
\hline & trol & $\begin{array}{l}4, \\
302\end{array}$ & & & \\
\hline \multirow{6}{*}{ Postes } & Eks & $\overline{75,8}$ & \multirow{6}{*}{$\begin{array}{c}4,109 \\
6\end{array}$} & \multirow{6}{*}{$\begin{array}{c}1,666 \\
2\end{array}$} & \multirow{6}{*}{$\begin{array}{l}\text { Ada } \\
\text { Perbe } \\
\text { daan } \\
\text { akiba } \\
\mathrm{t} \\
\text { peng } \\
\text { aruh }\end{array}$} \\
\hline & peri & 333 & & & \\
\hline & men & & & & \\
\hline & Kon & $\overline{64,5}$ & & & \\
\hline & trol & 349 & & & \\
\hline & & & & & \\
\hline
\end{tabular}

Pengujian hipotesis dalam penelitian ini meliputi uji perbedaan nilai akhir kelas eksperimen dan kelas kontrol. Setelah dilakukan pembelajaran pada kelas eksperimen dengan menggunakan model pembelajaran kooperatif tipe GI dan kelas kontrol menggunakan pembelajaran 
konvensional, diperoleh perhitungan uji hipotesis sebagai berikut : $t_{\text {hitung }}>t_{\text {tabel }}=(>$ 1,6662) maka $\mathrm{H}_{0}$ ditolak dan $\mathrm{H}_{\mathrm{a}}$ diterima dengan kata lain bahwa pengetahuan konseptual siswa pada kelas eksperimen lebih besar daripada kelas kontrol, berarti ada perbedaan pengetahuan konseptual siswa akibat pengaruh model pembelajaran kooperatif tipe GI (Group Investigation) pada materi pokok kinematika gerak lurus. Hasil pengujian hipotesis dapat dilihat pada Tabel 4.

Tabel 4. Hasil perhitungan uji t

Keterampilan siswa pada saat proses pembelajaran juga dinilai oleh peneliti. Aspek yang dinilai dari keterampilan siswa adalah merangkai alat, melakukan pengamatan, menganalisis data dan membuat kesimpulan. Penilaian keterampilan dilakukan di kelas eksperimen dengan menggunakan model inkuiri terbimbing, pada kelas kontrol tidak dilakukan penilaian keterampilan karena pada kelas kontrol tidak melakukan eksperimen. Rata-rata penilaian keterampilan mengalami kenaikan persentasi di setiap pertemuannya. Hasil rata-rata penilaian keterampilan disetiap aspek pada setiap pertemuannya ditunjukkan pada Tabel 5.

Tabel 5. Data penilaian keterampilan kelas eksperimen

\begin{tabular}{|c|c|c|c|}
\hline \multirow{2}{*}{ Aspek } & \multicolumn{3}{|c|}{ Pertemuan } \\
\cline { 2 - 4 } & I & II & III \\
\hline Merangkai alat & 72 & 80 & 82 \\
\hline $\begin{array}{c}\text { Melakukan } \\
\text { pengamatan }\end{array}$ & 71 & 77 & 87 \\
\hline Menganalisis data & 72 & 76 & 80 \\
\hline Menyimpulkan & 55 & 64 & 79 \\
\hline
\end{tabular}

Sikap siswa pada saat pembelajaran berlangsung juga diamati oleh peneliti. Penilaian sikap dilakukan pada kelas eksperimen dan kelas kontrol. Aspek yang dinilai adalah kedisiplinan, tanggung jawab, jujur, teliti, kreatif dan peduli. Hasil penilaian sikap disetiap aspek pada setiap pertemuannya ditunjukkan pada Tabel 6 .

Tabel 6. Data penilaian sikap kelas eksperimen dan kontrol

\begin{tabular}{|c|c|c|c|c|c|c|}
\hline \multirow{2}{*}{ Aspek } & \multicolumn{2}{|c|}{ Eksperimen } & \multicolumn{3}{c|}{ Kontrol } \\
\cline { 2 - 7 } & \multicolumn{2}{|c|}{ Pertemuan } & \multicolumn{3}{c|}{ Pertemuan } \\
\cline { 2 - 7 } & I & II & III & I & II & III \\
\hline Disiplin & 60 & 88 & 91 & 76 & 82 & 82 \\
\hline $\begin{array}{c}\text { Tanggung } \\
\text { jawab }\end{array}$ & 61 & 64 & 89 & 76 & 76 & 76 \\
\hline Jujur & 66 & 66 & 88 & 78 & 78 & 84 \\
\hline Teliti & 54 & 63 & 87 & 69 & 72 & 72 \\
\hline Kreatif & 54 & 80 & 85 & 67 & 67 & 72 \\
\hline Peduli & 76 & 74 & 78 & 54 & 61 & 79 \\
\hline
\end{tabular}

Aktivitas siswa juga dinilai pada saat pembelajaran berlangsung. Aspek yang dinilai adalah melakukan percobaan, mengumpulkan data, menganalisis data dan membuat kesimpulan. Penilaianan aktivitas hanya dilakukan di kelas eksperimen. Ratarata hasil penilaian aktivitas di setiap aspek pada setiap pertemuannya ditunjukkan pada Tabel 7.

Tabel 7. Nilai rata-rata aktivitas pada setiap pertemuan di kelas eksperimen

\begin{tabular}{|c|c|c|}
\hline Pertemuan & $\begin{array}{c}\text { Nilai } \\
\text { rata-rata }\end{array}$ & Kriteria \\
\hline I & 71 & Baik \\
\hline II & 80 & Amat baik \\
\hline III & 87 & Amat baik \\
\hline Rata-rata & 79 & Baik \\
\hline
\end{tabular}

Penelitian ini juga mengukur tingkat kesulitan belajar siswa dengan menggunakan angket yang berisi 29 pernyataan. Angket diberikan pada setian pertemuannya di kelas eksperimen karena peneliti ingin melihat ada tidaknya perbedaan kelas yang diberikan model pembelajaran inkuiri terbimbing dengan kelas yang diberikan pembelajaran konvensional. Angket kesulitan belajar ini terdiri dari 6 aspek, yaitu membaca, menulis, memahami bacaan, matematika, penyelesaian masalah, dan perhatian. Data penilaian kesulitan belajar siswa ditunjukkan pada Tabel 8.

Tabel 8. Penilaain kesulitan belajar siswa disetiap pertemuan

\begin{tabular}{|c|c|c|c|}
\hline \multirow{2}{*}{ Aspek } & \multicolumn{3}{|c|}{ Pertemuan } \\
\cline { 2 - 4 } & I & II & III \\
\hline Membaca & 60 & 56 & 45 \\
\hline Menulis & 65 & 61 & 52 \\
\hline Memahami bacaan & 67 & 62 & 55 \\
\hline
\end{tabular}




\begin{tabular}{|c|c|c|c|}
\hline Matematika & 68 & 57 & 53 \\
\hline $\begin{array}{c}\text { Penyelesaian } \\
\text { masalah }\end{array}$ & 63 & 57 & 53 \\
\hline Memperhatikan & 67 & 58 & 47 \\
\hline
\end{tabular}

Terjadi penurunan persentasi pada setiap pertemuannya, hal itu berarti pembelajaran inkuiri terbimbing mampu menurunkan persentasi kesulitan belajar siswa.

\section{Pembahasan}

Berdasarkan hasil penelitian yang dilakukan setelah kedua kelas diberi perlakuan yang berbeda yaitu pada kelas eksperimen menggunakan model inkuiri terbimbing dan kelas kontrol menggunakan pembelajaran konvensional. Hasil belajar dengan menggunakan pembelajaran inkuiri terbimbing lebih tinggi daripada menggunakan pembelajaran konvensional, dengan kata lain hasil belajar di kelas eksperimen dengan menggunakan model inkuiri terbimbing memiliki pengaruh yang signifikan. Hal ini dikarenakan pada proses pembelajaran melakukan eksperimen, dimana pada kegiatan ini siswa dilatih merencanakan prosedur percobaan sendiri untuk memecahkan masalah, guru memfasilitasi penyelidikan dan mendorong siswa mengungkapkan atau membuat pertanyaan-pertanyaan yang membimbing mereka untuk penyelidikan hingga menemukan konsep yang sedang dipelajari.

Penerapan model pembelajaran inkuiri terbimbing juga mampu meningkatkan nilai sikap, keterampilan dan aktivitas siswa selama proses pembelajaran berlangsung. Aspek keterampilan mengalami peningkatan nilai persentase pada setiap aspeknya, terutama pada aspek melakukan pengamatan dan membuat kesimpulan. Siswa menjadi lebih tertarik untuk melakukan pengamatan dan menemukan hal baru sehingga mereka mampu membuat kesimpulannya sendiri pada saat menutup pembelajaran.

Sikap siswa yang diberikan perlakuan model pembelajaran inkuiri terbimbing juga mengalami kenaikan persentase pada tiap aspeknya. Yang mengalami kenaikan paling tinggi adalah pada aspek teliti. Siswa dituntut untuk teliti pada saat melakukan eksperimen karena jika salah melakukan eksperimen maka siswa juga akan salah dalam membuat hipotesis yang akan dibentuk lagi menjadi sebuah konsep yang benar. Penelitian ini juga melihat bagaimana aktivitas siswa dengan menggunakan model pembelajaran inkuiri, ternyata didapatkan hasil persentasi yang meningkat pada setiap pertemuan.

Model pembelajaran inkuiri terbimbing dapat membantu mengatasi kesulitan belajar siswa pada saat proses belajar mengajar. Hal ini disebabkan karena pembelajaran inkuiri terbimbing dimaksudkan untuk membimbing siswa menemukan konsep secara mandiri dengan melakukan kegiatan penyelidikan melalui eksperimen. Penemuan konsep tersebut berawal dari fakta-fakta yang dikumpulkan siswa secara langsung pada saat melakukan eksperimen. Fakta-fakta yang ditemukan siswa lalu dikumpulkan menjadi sebuah gagasan dan dari gagasan itu akan dibentuk menjadi suatu konsep.

Kegiatan yang dilakukan siswa tersebut juga membantu siswa dalam meningkatkan hasil belajar siswa, karena siswa menjadi lebih aktif dalam memperoleh pengetahuan melalui eksperimen yang dilakukan bukan hanya sekedar mendengar atau menerima informasi yang disampaikan guru. Hal ini didukung oleh Wijayanti, dkk., (2010) yang mengatakan bahwa pembelajaran inkuiri terbimbing pada pokok bahasan cahaya khususnya pemantulan cahaya dapat mengatasi kesulitan belajar siswa yang berdampak pada peningkatan hasil belajar siswa. Gonzales dan Stone (2007) mengatakan bahwa siswa yang mengalami kesulitan dalam belajar fisika dengan indikasi nilai yang rendah dan di bawah rata-rata perlu diberikan pembelajaran yang dapat lebih membuat para siswa memahami apa yang dipelajari dengan melakukan praktek secara langsung dengan bimbingan dari guru, karena dengan melakukan 
eksperimen siswa lebih memiliki interaksi langsung dengan pengetahuan yang dia pelajari.

\section{KESIMPULAN DAN SARAN Kesimpulan}

Berdasarkan hasil penelitian yang diperoleh dari hasil analisis dan pengujian hipotesis maka dapat disimpulkan sebagai berikut: (1) Pembelajaran inkuiri terbimbing khususnya pada pokok bahasan kinematika gerak lurus dapat mengatasi kesulitan belajar siswa, persentase kesulitan belajar yang dialami siswa mengalami penurunan pada setiap pertemuannya. (2) Pembelajaran inkuiri terbimbing khususnya pada pokok bahasan kinematika gerak lurus menyebabkan meningkatnya hasil belajar siswa yang ditunjukkan dengan peningkatan nilai postes yang diiringi degan terpenuhinya ketuntasan belajar dari sebelum dan setelah dilakukan penelitian. (3) Pembelajaran konvensional khususnya pada pokok bahasan kinematika gerak lurus memiliki nilai postes yang belum mencukupi nilai ketuntasan.

\section{Saran}

Berdasarkan hasil dan kesimpulan dalam penelitian ini, maka peneliti mempunyai beberapa saran, yaitu: (1) Bagi para peneliti yang ingin menggunakan model inkuiri terbimbing, agar mendapatkan hasil yang lebih baik, disarankan untuk memastikan bahwa sekolah memiliki sarana dan prasarana yang mendukung. (2) Bagi para peneliti selanjutnya agar lebih memperhatikan dalam pembagian kelompok yang sebaiknya jumlah siswa dalam setiap kelompok cukup 5-4 orang.

\section{DAFTAR PUSTAKA}

Arikunto, S., (2010), Prosedur Penelitian Suatu Pendidikan Praktik, PT. Rineka Cipta, Jakarta.

Gonzales, W.J. \& Stone, M. 2017. Guiding Experiences in Physics Instruction for Undergraduates. Journal Physics Teaching Education Online 3(1).

Sudjana, (2005). Metoda Statistika. Penerbit Tarsito: Bandung.

Wijayanti. (2010). Eksplorasi Kesulitan Belajar Siswa pada Pokok Bahasan Cahaya dan Upaya Peningkatan Hasil Belajar melalui Pembelajaran Inkuiri Terbimbing. Jurnal Pendidikan Fisika Indonesia. Semarang: Universitas Negeri Semarang. 